\title{
KANKER LEHER RAHIM (CANCER CERVIX) SEBAGAI PEMBUNUH WANITA TERBANYAK DI NEGARA BERKEMBANG
}

\author{
Cahyawati Arisusilo \\ Jurusan Biologi Fakultas Sains dan Teknologi UIN Maliki Malang
}

\begin{abstract}
Worldwide, cervical cancer is twelfth most common (Edward, 2010) and the fifth most deadly cancer in women (Globocan, 2002). It affects about 16 per 100,000 women per year and kills about 9 per 100,000 per year (WHO, 2006). Approximately $80 \%$ of cervical cancers occur in developing countries (Kent, 2010). Worldwide, in 2008, it was estimated that there were 473,000 cases of cervical cancer, and 253,500 deaths per year (NCC, 2008).

Cervical cancer is the leading cause of cancer death in most developing countries (Edianto, 2006). Counted as many as 510,000 new cases occur each years and lasts more than 288,000 deaths from the disease worldwide. Low incidence of this disease in women aged under 25 years old, but the incidence increases in women aged 35 to 40 years and reached a maximum at the age of the 50's. Meanwhile, the incidence of cervical cancer it self continues to increase from about 25 per 100,000 in 1988 to around 32 per 100,000 in 1992 (Edianto, 2006).
\end{abstract}

In 2005, the number of women aged 15-64 years in Indonesia is 65 million and the prevalence of cervical cancer is 50 per 100,000 women. This means the number of patients with cervical cancer is approximately 32500 patients. Patients with stage I as much as 7\% or 2275, stage Ib-IIa by $28 \%$ or 9100, and a stage IIB-IV by $65 \%$ or 21 125 patients (Rasjidi, 2007). This data showed that cancer cervix detected mostly on late stages, so it commonly called silent diseases.

The uterine cervix is the lowest portion of a woman's uterus (womb). Most of the uterus lies in the pelvis, but part of the cervix is located in the vagina, where it connects the uterus with the vagina.

Cancer of the cervix occurs when the cells of the cervix change in a way that leads to abnormal growth and invasion of other tissues or organs of the body. Like all cancers, cancer of the cervix is much more likely to be cured if it is detected early and treated immediately. One of the key features of cervical cancer is its slow progression from normal cervical tissue, to precancerous (or dysplastic) changes in the tissue, to invasive cancer. The slow progression through numerous precancerous changes is very important because it provides opportunities for prevention and early detection and treatment.

Invasive cancer means that the cancer affects the deeper tissues of the cervix and may have spread to other parts of the body. This spread is called metastasis. Cervical cancers don't always spread, but those that do most often spread to the lungs, the liver, the bladder, the vagina, and/or the rectum. Invasive cancer this way could caused death.

This literature review is intended to improve the understanding of cervical cancer that is expected to impact on improving health services in particular increased levels of knowledge about cervical cancer and its prevention at an early stage to reduce the incidence of cervical cancer and the death because of it, especially in Indonesia. 


\section{PENDAHULUAN}

Kanker merupakan terbentuknya suatu jaringan baru yang kemudian menginvasi dan menghancurkan jaringan sekitar yang masih sehat. Pada keadaan kanker sel selaput lendir serviks melakukan proliferasi (membelah dan tumbuh) yang diawali dengan membentuk susunan sel seperti kelenjar, dengan permukaan seperti karet busa (spongiform) yang kaya dengan pembuluh darah (Davison, 2004).

Hingga saat ini kanker serviks merupakan penyebab kematian terbanyak penyakit kanker di negara berkembang (Edianto, 2006). Terhitung sebanyak 510.000 kasus baru terjadi tiap tahun dan lebih dari 288.000 kematian berlangsung akibat penyakit ini di seluruh dunia. Angka kejadian penyakit ini rendah pada wanita berumur dibawah 25 tahun, namun insidensi meningkat pada wanita berumur 35 sampai 40 tahun dan mencapai titik maksimum pada usia 50an.

Sementara itu, insidensi kanker serviks sendiri terus meningkat dari sekitar 25 per 100.000 pada tahun 1988 menjadi sekitar 32 per 100.000 pada 1992. Dari seluruh gambaran dan data global mengenai kanker serviks, penyakit ini memiliki indeks rasio yang lebih tinggi hingga 5 sampai 6 kali pada negara-negara berkembang (Edianto, 2006).

Di Indonesia sendiri pada tahun 2005 , jumlah perempuan yang berumur 15-64 tahun adalah 65 juta dan prevalensi kanker serviks adalah 50 per 100.000 perempuan. Ini berarti jumlah penderita kanker serviks adalah sekitar 32.500 penderita. Dari sejumlah data diatas, penderita dengan stadium Ia sebanyak $7 \%$ atau 2.275 , stadium Ib-lia sebanyak $28 \%$ atau 9.100 , dan stadium lib-IV a sebanyak $65 \%$ atau 21.125 penderita (Rasjidi, 2007). Hal ini terlihat bahwa kanker serviks sering terdeteksi pada stadium lanjut sehingga sering disebut juga sebagai silent disease.

Dari paparan diatas maka literatur review ini ditujukan untuk meningkatkan pemahaman terhadap kanker serviks sehingga diharapkan dapat berdampak terhadap peningkatan pelayanan kesehatan khususnya peningkatan tingkat pengetahuan mengenai kanker serviks, dan cara pencegahannya secara dini untuk menurunkan insidensi kanker serviks khususnya di Indonesia. 


\section{Pengertian}

Kanker serviks biasa dikenal dengan kanker leher rahim yang terjadi pada daerah leher rahim. Yaitu daerah pada organ reproduksi wanita yang merupakan pintu masuk ke arah rahim. Letaknya antara rahim (uterus) dengan liang senggama wanita (vagina).

Serviks terletak pada bagian posisi terendah dari rahim wanita. Sebagian besar rahim terletak di panggul, tapi bagian dari serviks terletak di vagina, di mana ia menghubungkan rahim dengan vagina. Kanker serviks terjadi ketika sel-sel dari leher rahim mengalami pertumbuhan yang mengarah pada pertumbuhan secara tidak normal dan menginvasi jaringan lain atau organ-organ tubuh. Seperti semua kanker pada umumnya, kanker leher rahim jauh lebih mungkin untuk disembuhkan jika dideteksi dini dan segera diobati.

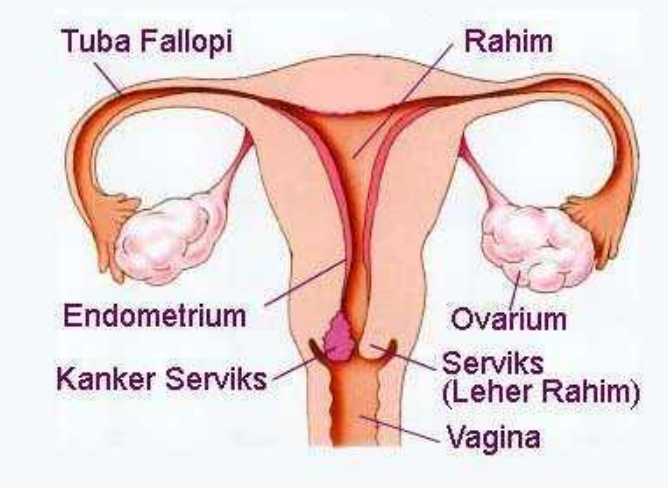

\section{Penyebab}

Disebabkan Infeksi Human Papilloma Virus (HPV) tipe 16 dan 18. Penelitian menunjukkan bahwa 10-30\% wanita pada usia 30'an tahun yang sexually active pernah menderita infeksi HPV (termasuk infeksi pada daerah vulva). Persentase ini semakin meningkat bila wanita tersebut memiliki banyak pasangan seksual. Pada sebagian besar kasus, infeksi HPV berlangsung tanpa gejala dan bersifat menetap (Kumar, 2007; Walboomers, 1999).

\section{Faktor resiko}

- Usia

Perempuan yang rawan mengidap kanker serviks adalah mereka yang berusia antara 35-50 tahun, terutama anda yang telah aktif secara seksual sebelum usia 16 tahun. Hubungan seksual pada usia terlalu dini bisa meningkatkan risiko terserang kanker leher rahim sebesar 2 kali dibandingkan perempuan yang melakukan hubungan seksual setelah usia 20 tahun (Canavan, 2000).

Semakin tua seorang wanita maka makin tinggi risikonya terkena 
kanker serviks. Tentu kita tidak bisa mencegah terjadinya proses penuaan. Akan tetapi kita bisa melakukan upaya-upaya lainnya untuk mencegah meningkatnya risiko kanker serviks.

- Jumlah Perkawinan - sering berganti-ganti pasangan (multipatner sex)

Semakin banyak berganti-ganti pasangan maka tertularnya infeksi HPV juga semakin tinggi. Hal ini disebabkan terpaparnya sel-sel mulut rahim yang mempunyai $\mathrm{pH}$ tertentu dengan spermasperma yang mempunyai $\mathrm{pH}$ yang berbeda-beda pada multipatner, sehingga dapat merangsang terjadinya perubahan kearah displasia.

Dalam Islam Allah SWT telah memberikan perintahnya untuk menjauhi perbuatan zina,

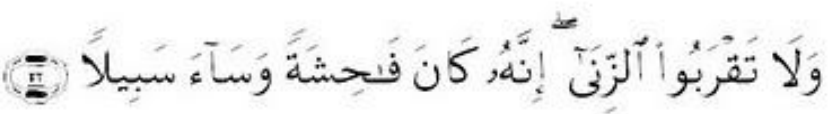

Artinya : "Dan janganlah kamu mendekati zina; Sesungguhnya zina itu adalah suatu perbuatan yang keji. dan suatu jalan yang buruk." (Q.S. Al-Isra : 32)

- Wanita merokok

Merokok dapat menurunkan daya tahan tubuh. Ada banyak penelitian yang menyatakan hubungan antara kebiasaan merokok dengan meningkatnya risiko seseorang terjangkit penyakit kanker serviks. Salah satunya adalah penelitian yang dilakukan di Karolinska Institute di Swedia dan dipublikasikan di British Journal of Cancer pada tahun 2001.

Menurut Joakam Dillner, M.D., peneliti yang memimpin riset tersebut, zat nikotin serta "racun" lain yang masuk ke dalam darah melalui asap rokok mampu meningkatkan kemungkinan terjadinya kondisi cervical neoplasia atau tumbuhnya selsel abnormal pada rahim. Dimana Cervical neoplasia adalah kondisi awal berkembangnya kanker serviks di dalam tubuh seseorang (ACA, 2010; MD, 2006)

Dalam Alquran Allah SWT menyuruh mereka (umat muslim) mengerjakan yang makruf dan melarang mereka dari mengerjakan yang mungkar dan menghalalkan bagi mereka segala yang baik dan mengharamkan bagi mereka segala yang buruk." (QS. AlA'raf : 157)

- Hygiene dan sirkumsisi

Keputihan yang dibiarkan terus menerus tanpa diobati serta Penyakit Menular Seksual (PMS) yaitu penyakitpenyakit yang ditularkan melalui 
Kanker Leher Rahim (Cancer Cervix) Sebagai ...

hubungan seksual antara lain sifilis, gonore, herpes simpleks, HIV-AIDS, kutil kelamin dapat meningktakan resiko terjadinya kanker serviks.

Pemakaian pembalut yang mengandung bahan dioksin. Dioksin merupakan bahan pemutih yang digunakan untuk memutihkan pembalut hasil daur ulang dari barang bekas, misalnya krayon, kardus, dan lain-lain. Membasuh kemaluan dengan air yang tidak bersih, misalnya di toilet-toilet umum yang tidak terawat. Air yang tidak bersih banyak dihuni oleh kumankuman.

Laki-laki yang melakukan
sirkumsisi (khitan) memiliki
kemungkinan yang kecil untuk
terjangkiti HPV. Dengan dilakukannya
sirkumsisi maka kebersihan dari organ
genital dapat lebih terpelihara. (ACA,
2010).

Khitan secara bahasa artinya memotong. Secara terminologis artinya memotong kulit yang menutupi alat kelamin lelaki (penis). Dalam bahasa Arab khitan juga digunakan sebagai nama lain alat kelamin lelaki dan perempuan seperti dalam hadist yang mengatakan "Apabila terjadi pertemuan dua khitan, maka telah wajib mandi” (H.R. Muslim, Tirmidzi dll.).
Dalam agama Islam, khitan merupakan salah satu media pensucian diri dan bukti ketundukan kita kepada ajaran agama. Dalam hadist Rasulullah s.a.w. bersabda:"Kesucian (fitrah) itu ada lima: khitan, mencukur bulu kemaluan, mencabut bulu ketiak, memendekkan kumis dan memotong kuku” (H.R. Bukhari Muslim).

- Status sosial ekonomi

Kemiskinan merupakan salah satu faktor resiko terjadinya kanker serviks, karena pada wanita dengan tingkat pendapatan yang rendah akan mengalami kesulitan untuk melaksanakan pelayanan kesehatan yang adekuat termasuk didalamnya melakukan Pap Smear. Hal ini menyebabkan wanita-wanita dari golongan ini tidak terscreening dan tentunya tidak dapat dideteksi dini maupun mendapatkan terapi dini apabila terserang kanker serviks (ACA, 2010).

- Gizi buruk

Para penderita gizi buruk berisiko terinfeksi virus HPV. seseorang yang melakukan diet ketat, dengan disertai rendahnya konsumsi vitamin A, $\mathrm{C}$, dan E setiap hari bisa menyebabkan berkurangnya tingkat kekebalan pada tubuh, sehingga Anda mudah terinfeksi. 


\section{Vitamin A}

Kekurangan yang signifikan dari retinol dapat meningkatkan kemungkinan displasia serviks, infeksi HPV secara independen (Yeo, 2000).

\section{Vitamin C}

Perempuan dengan nilai asupan vitamin $\mathrm{C}$ rendah memiliki kemungkinan terjangkit virus HPV yang lebih tinggi (Guiliano, 2003).

\section{Vitamin E}

Kandungan alfa-tokoferol rendah sering terdapat pada penderita HPV-positif dengan intraepithelial neoplasia serviks. Dan risiko terjadinya displasia adalah empat kali lebih tinggi untuk tingkat alfa-tokoferol $<7,95 \mathrm{mmol}$ / 1 (Kwasniewska (1997).

- Terpajan virus terutama virus HIV

Human immunodeficiency virus (HIV), virus penyebab AIDS, merusak sistem kekebalan pada wanita. Hal ini dapat menjelaskan peningkatan risiko kanker serviks bagi wanita dengan AIDS. Para ilmuwan percaya bahwa sistem kekebalan tubuh adalah penting dalam menghancurkan sel-sel kanker dan memperlambat pertumbuhan serta penyebaran. Pada wanita dengan HIV, kanker pra serviks bisa berkembang menjadi kanker invasif lebih cepat dari biasanya (ACA, 2010).

\section{Penularan}

Penularan virus HPV bisa terjadi melalui hubungan seksual, terutama yang dilakukan dengan berganti-ganti pasangan. Penularan virus ini dapat terjadi baik dengan cara transmisi melalui organ genital ke organ genital, oral ke genital, maupun secara manual ke genital.

\section{Gejala}

Pada tahap awal, penyakit ini tidak menimbulkan gejala yang mudah diamati. Itu sebabnya, Anda yang sudah aktif secara seksual amat dianjurkan untuk melakukan tes pap smear setiap dua tahun sekali. Gejala fisik serangan penyakit ini pada umumnya hanya dirasakan oleh penderita kanker stadium lanjut.

Gejala kanker serviks tingkat lanjut :

- munculnya rasa sakit dan perdarahan saat berhubungan intim (contact bleeding).

keputihan yang berlebihan dan tidak normal.

perdarahan di luar siklus menstruasi.

penurunan berat badan drastis. 
Kanker Leher Rahim (Cancer Cervix) Sebagai ...

- Apabila kanker sudah

menyebar ke panggul, maka pasien akan menderita keluhan nyeri punggung

- juga hambatan dalam

berkemih, serta pembesaran ginjal. $1,6,7$

Masa preinvasif (pertumbuhan sel-sel abnormal sebelum menjadi keganasan) pada penyakit ini terbilang cukup lama, sehingga penderita yang berhasil mendeteksinya sejak dini dapat melakukan berbagai langkah untuk mengatasinya.

$$
\text { Infeksi menetap akan }
$$

menyebabkan pertumbuhan sel abnormal yang akhirnya dapat mengarah pada perkembangan kanker. Perkembangan ini memakan waktu antara 5-20 tahun, mulai dari tahap infeksi, lesi pra-kanker hingga positif menjadi kanker serviks.

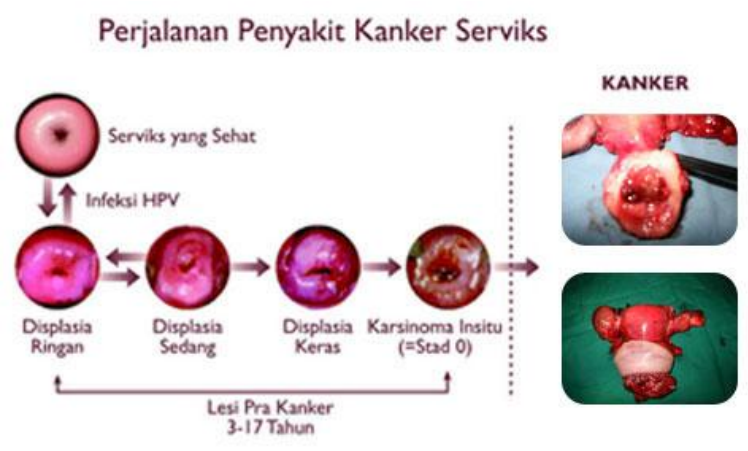

Gambar 2. Perjalanan Kanker Serviks 


\section{Sitologi, dengan cara pap smear}

Tes Pap : Tes ini merupakan untuk mendeteksi infeksi HPV dan prakanker serviks. Ketepatan diagnostik sitologinya $90 \%$ pada displasia berat dan $76 \%$ pada dysplasia ringan / sedang. Didapatkan hasil negatif palsu $5-50 \%$ sebagian besar disebabkan pengambilan sediaan yang tidak adekuat. Sedangkan hasil positif palsu sebesar 3-15\%.

Pap smear dapat dilakukan pada saat pemeriksaan dalam rutin. Pap smear merupakan metode skrining yang sudah dikenal luas. Dokter Anda akan menggunakan spekulum untuk melihat serviks. Selanjutnya dengan menggunakan alat khusus (sikat yang halus), dilakukan pengambilan sel-sel di sekitar serviks. Kemudian sel-sel tersebut dipulas pada kaca objek dan dikirimkan ke laboratorium untuk diperiksa. Pap smear biasanya tidak nyeri, tetapi kurang nyaman bagi sebagian perempuan. Bagi perempuan yang sudah melakukan hubungan seksual, lakukan deteksi dini secara rutin. Deteksi dini dapat mendeteksi sel abnormal, lesi pra-kanker dan kanker serviks namun tidak dapat mencegah terjadinya infeksi HPV. Kanker serviks yang ditemukan pada stadium dini dan diobati dengan cepat dan tepat dapat disembuhkan, oleh sebab itu lakukan deteksi dini secara berkala. Resiko berkembangnya infeksi menjadi kanker serviks adalah 3-10 kali lebih tinggi pada perempuan yang tidak menjalankan deteksi dini secara teratur.

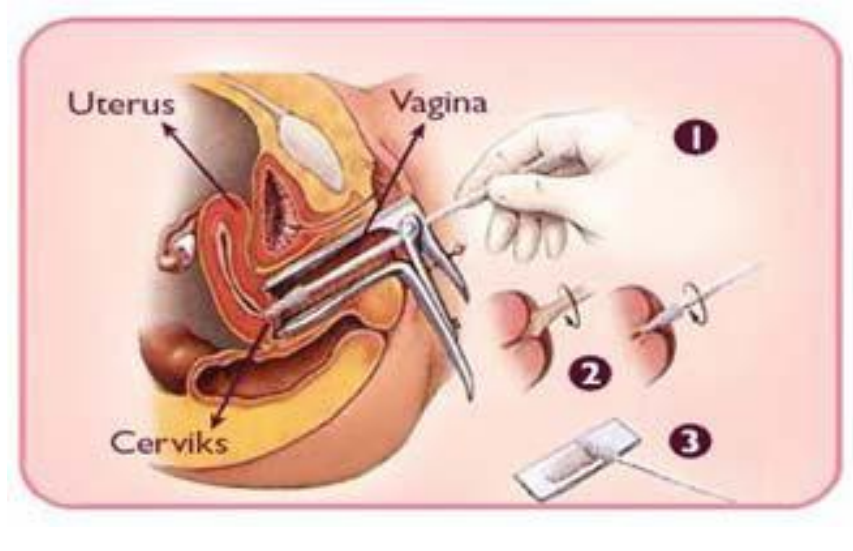

Gambar 3. Deteksi Dini

\section{IVA (Inspeksi Visual dengan Asam} Asetat)

IVA adalah skrining yang dilakukan dengan memulas serviks menggunakan asam asetat 3-5\% dan kemudian diinspeksi secara kasat mata oleh tenaga medis yang terlatih. Setelah serviks diulas dengan asam asetat, akan terjadi perubahan warna pada serviks yang dapat diamati secara langsung dan dapat dibaca sebagai normal atau abnormal.

\section{Vaksinasi HPV}


Pada pertengahan tahun 2006 telah beredar vaksin pencegah infeksi HPV tipe 16 dan 18 yang menjadi penyebab kanker serviks. Vaksin ini bekerja dengan cara meningkatkan kekebalan tubuh dan menangkap virus sebelum memasuki sel-sel serviks. Selain membentengi dari penyakit kanker serviks, vaksin ini juga bekerja ganda melindungi perempuan dari ancaman HPV tipe 6 dan 11 yang menyebabkan kutil kelamin.

Vaksin ini membutuhkan serangkaian 3 suntikan dalam periode 6 bulan. Efek samping yang biasanya ringan. Yang paling umum adalah jangka pendek kemerahan, bengkak, dan nyeri di tempat suntikan. Terdapat dua jenis vaksin HPV yaitu Cevarix dan Gardasil. Cervarix telah disetujui untuk digunakan pada anak perempuan dan wanita muda usia 10 sampai 25 tahun, sementara Gardasil telah disetujui untuk digunakan pada kedua jenis kelamin berusia 9 sampai 26 tahun. Dalam uji klinis, kedua vaksin mencegah kanker serviks dan pra-kanker yang disebabkan oleh HPV tipe 16 dan 18. Gardasil juga mencegah dubur, vagina, dan kanker vulva yang disebabkan oleh jenis-jenis HPV, serta kutil kelamin disebabkan oleh HPV tipe 6 dan 11. Kedua Gardasil dan Cervarix hanya bekerja untuk mencegah infeksi HPV - mereka tidak akan mengobati infeksi yang sudah ada. Itu sebabnya, untuk menjadi yang paling efektif, vaksin HPV harus diberikan sebelum seseorang mulai berhubungan seks.

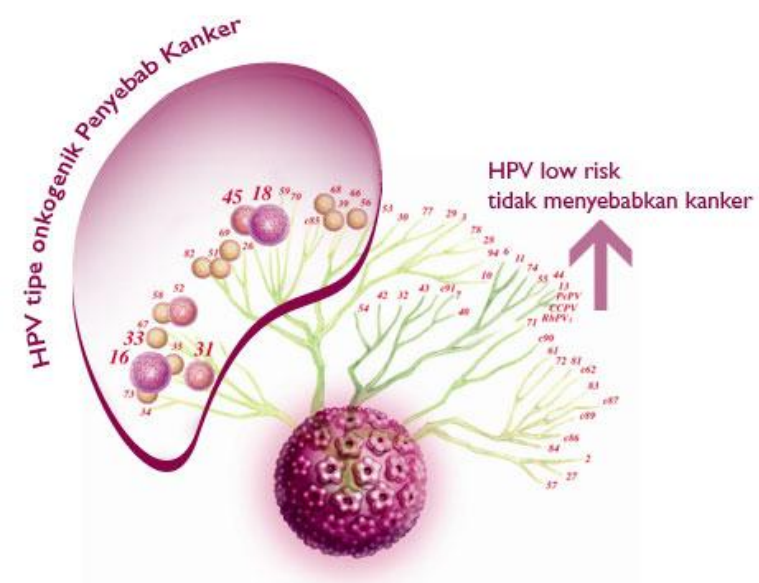

Gambar 4. HPV Onkogenik dan non Onkogenik

\section{Pemberian Vaksin}

Untuk pencegahan infeksi oleh HPV onkogenik penyebab kanker, vaksinasi sebaiknya dilakukan sedini mungkin dan dapat diberikan mulai remaja putri berusia 10 tahun. Pemberian vaksinasi dianjurkan karena :

- Seorang perempuan dapat terkena HPV semasa hidupnya.

- Infeksi HPV terdahulu tidak memberikan kekebalan terhadap infeksi berikutnya.

- Data menunjukkan saat seorang perempuan bertambah usia, infeksi HPV menetap dan berpotensi 
memicu lesi pra kanker dan dapat menyebabkan kanker.

Rekomendasi pemberian vaksin dilakukan pada perempuan berusia 10 - 55 tahun dengan jadwal pemberian vaksin pada bulan 0,1 atau 2, dan 6. Dengan dilakukannya vaksinasi, risiko terkena kanker serviks bisa menurun hingga $75 \%$.

\section{KESIMPULAN}

Berhubung tidak mengeluhkan gejala apa pun, penderita kanker serviks biasanya datang ke rumah sakit ketika penyakitnya sudah mencapai stadium 3 . Masalahnya, kanker serviks yang sudah mencapai stadium 2 sampai stadium 4 telah mengakibatkan kerusakan pada organ-organ tubuh, seperti kandung kemih, ginjal, dan lainnya. Karenanya, operasi pengangkatan rahim saja tidak cukup membuat penderita sembuh seperti sedia kala. Selain operasi, penderita masih harus mendapatkan terapi tambahan, seperti radiasi dan kemoterapi. Langkah tersebut sekalipun tidak dapat menjamin $100 \%$ penderita mengalami kesembuhan. Sehingga perlu dipikirkan lebih lanjut untuk mencegah atau mengobati dimana prosedur pengangkatan rahim, radiasi dan kemoteraphy juga belum memiliki jaminan kesembuhan.

Cobaan atau ujian adalah rekayasa Ilahiyah untuk menyeleksi hamba-hamba-Nya. Cobaan diberikan oleh Allah dengan maksud untuk meningkatkan kualitas hidup manusia. Bagi yang lulus akan naik derajat. Sebaliknya, bagi mereka yang tidak lulus ada dua alternatif pilihan, yaitu tetap ditempat atau justru melorot jatuh ke derajat yang lebih rendah. Begitu pula dengan adanya penyakit dalam tubuh manusia merupakan coabaan dari Allah SWT.

Dengan kata lain, tidak ada satupun manusia di muka bumi ini dibiarkan oleh Allah berlalu tanpa mendapatkan ujian. Apalagi bagi mereka yang telah mengaku sebagai orang yang beriman, maka pengakuan itu perlu pembuktian. Hanya melalui ujian yang datang silih berganti, seseorang dapat membuktikan keimanannya kepada Allah SWT. Dan Allah telah menegaskan dalam firmanNya:

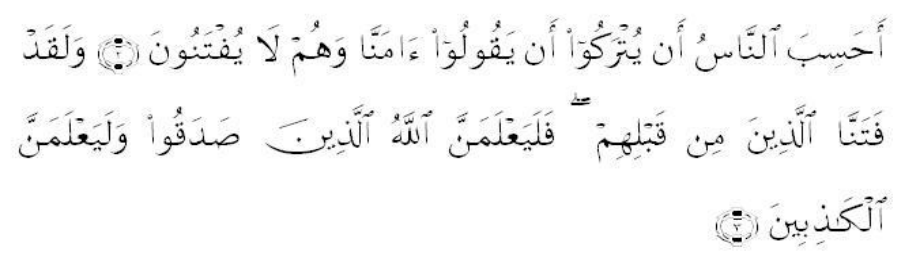


Kanker Leher Rahim (Cancer Cervix) Sebagai ...

Artinya : "Apakah manusia mengira bahwa mereka akan dibiarkan mengatakan, 'Kami telah beriman, sedangkan mereka tidak diuji lagi?” (QS AlAnkabuut: 2).

Kita harus yakin bahwa setelah dalam kesulitan pasti ada kemudahan. Allah subhanahu wa ta'ala berfirman dalam surat Al Insyirah ayat 5-6:

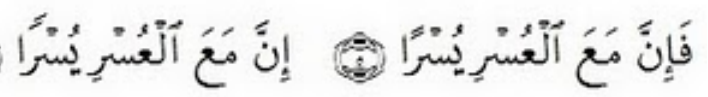

Artinya : "Karena sesungguhnya sesudah kesulitan itu ada kemudahan. Sesungguhnya sesudah kesulitan itu ada kemudahan."

Kita juga harus selalu optimis bahwa kita bisa menyelesaikan setiap ujian yang Allah berikan, karena Allah subhanahu wa ta'ala tidak akan memberikan ujian di luar kemampuan hamba-Nya. Optimisme bisa melahirkan energi yang tersembunyi dalam diri kita, karena itu optimisme bisa menjadi bahan bakar untuk menyelesaikan segala persoalan.
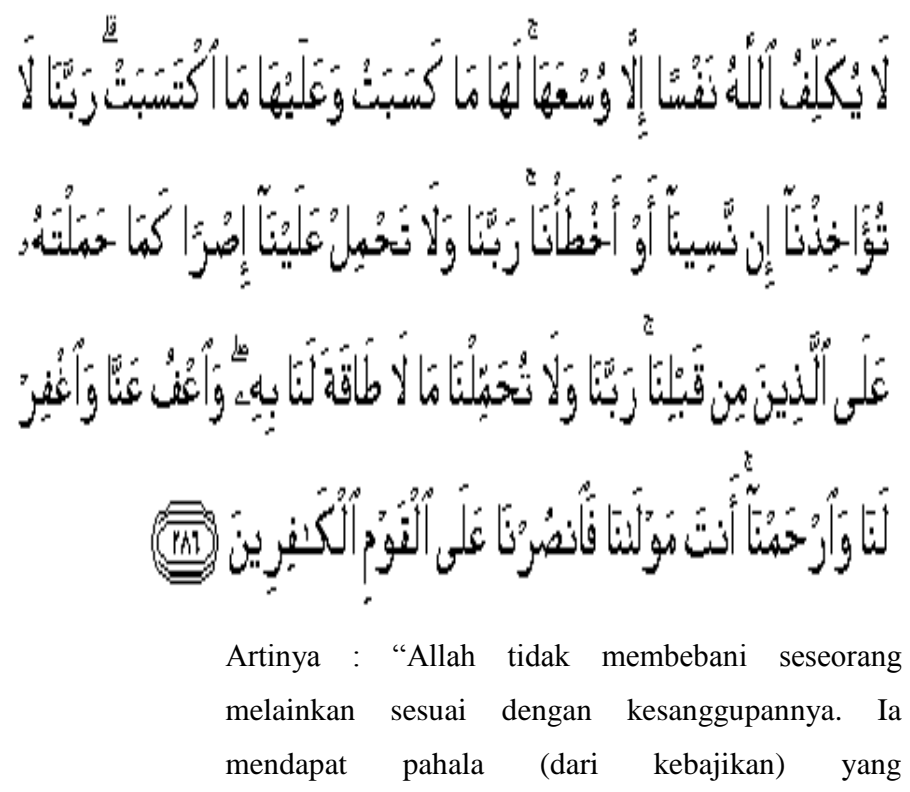

diusahakannya dan ia mendapat siksa (dari kejahatan) yang dikerjakannya.” (QS. Al-Baqarah: 286).

Senantiasa menghadapi ujian dengan usaha dan do'a. Kerahkan segala ikhtiar untuk menyelesaikan setiap ujian, dan bingkai usaha itu dengan do'a. "Maka apabila kamu telah selesai (dari suatu urusan), maka kerjakanlah dengan sungguh-sungguh (urusan) yang lain. Dan hanya kepada Tuhanmulah hendaknya kamu berharap.” (QS. A1 Insyirah: 7-8).

Dimana salah satu bentuk usaha adalah dengan senantiasa melakukan pencegahan, dan menjaga karunia Allah SWT dengan sebaik-baiknya, menjalankan perintahNya dan menjauhi laranganNya.

\section{DAFTAR PUSTAKA}

American Cancer Society. 2010. "What are the risk factors for cervical cancer?". Retrieved 1 oktober 2011.

Canavan TP, Doshi NR (2000). "Cervical cancer.". Am Fam Physician 61 (5): 1369-76. $\underline{\text { PMID }}$ 10735343. Retrieved 1 oktober 2011.

Davison, G.C., Neale, J. M., \& Kring, A. M (2004). Abnormal psychology $9^{\text {th }}$ ed. Hoboken, NJ : John Wiley \& Sons.

Dinshaw, KA, 2010. Guidelines for Management of Cervix Cancer. 
Indian Council of Medical Research. New Delhi.

Edianto, D (2006). Kanker Serviks dalam M.F Aziz, Andrijono, Buku Acuan Nasional : Onkologi Ginekologi. Jakarta: Yayasan Bina Pustaka Sarwono Prawirohardjo

Edward P. Armstrong,2010. "Prophylaxis of Cervical Cancer and Related Cervical Disease: A Review of the CostEffectiveness of Vaccination Against Oncogenic HPV Types". Journal of Managed Care Pharmacy

GLOBOCAN 2002 database: summary table by cancer". Archived from the original on 2008-06-16. Retrieved 1 oktober 2011.

Giuliano AR, Siegel EM, Roe DJ, et al (2003). "Dietary intake and risk of persistent human papillomavirus (HPV) infection: the Ludwig-McGill HPV Natural History Study". J. Infect. Dis.

Imam Rasjidi, dr, Sp.OG (K) Onk (2007). Panduan Penatalaksanaan Kanker Ginekologi Berdasarkan Evidence Base Editor. EGC, Jakarta.

Kumar, Vinay; Abbas, Abul K.; Fausto, Nelson; \& Mitchell, Richard N. (2007). Robbins Basic Pathology ((8th ed.) ed.). Saunders Elsevier. pp. 718-721. ISBN 978-1-4160-2973-1.
Kwaśniewska A, Tukendorf A, Semczuk M (1997). "Content of alpha-tocopherol in blood serum of human Papillomavirusinfected women with cervical dysplasias". Nutrition and cancer

Michaëlsson K, Lithell H, Vessby B, Melhus H. (2003). "Serum Retinol Levels and the Risk of Fracture". NEJM 348 (4): 287294.

Sedjo RL, Roe DJ, Abrahamsen M, et al (2002). "Vitamin A, carotenoids, and risk of persistent oncogenic human papillomavirus infection". Cancer Epidemiol. Biomarkers Prev.

Walboomers JM, Jacobs MV, Manos MM, et al (1999). "Human papillomavirus is a necessary cause of invasive cervical cancer worldwide". J. Pathol.

WebMD. "Smoking Boosts Cervical Cancer Risk". Retrieved1 oktober 2011

World Health Organization (February 2006). "Fact sheet No. 297: Cancer". Retrieved 1 oktober 2011

Yeo AS, Schiff MA, Montoya G, Masuk M, van Asselt-King L, Becker TM (2000). "Serum micronutrients and cervical dysplasia in Southwestern American Indian women". Nutrition and cancer 38 (2): 141-50. 